\title{
A NOTE ON BERIS ANNULIFERA (BIGOT).
}

\author{
By Charles W. Johnson. \\ Boston Society of Natural History.
}

This seems to represent an extremely. variable species. Specimens with all the femora and tibiæ yellow, have been referred to B. morrisii Dale, a European species, which has however quite a different genitalia. I have not seen a typical morrisii from America. Numerous specimens from New England and Canada agree with Bigot's description although "Georgie" is given as the type locality. In a series of fifty-two specimens I am unable to find characters of specific value, but there seem to be three quite marked varieties, based on the general color of the legs. Notwithstanding the fact that intermediate forms exist, it seems well to consider these varieties rather than to have Bigot's description the only means of determining this variable and widely distributed species.

\section{Beris annulifera (Bigot).}

Oplacantha annulifera Bigot, Ann. Soc. Ent. France, 1887, p. 21.

Legs yellow, the posterior femora with a more or less prominent sub-apical band of brownish black, tarsi black with the base of the metatarsi yellowish. Its distribution is as follows: Bretton Woods, N. H., June 24, Oquossoc, Me., July 2, (C. W. J.), Lake Nipigon, July 4 and Lake Abittibi, Ontario, June 23 (N. K. Bigelow), English River and Athabasca River, (Kennicot) N. Calif., (Mus. Comp. Zool.) Alaska, (Coquillett).

Around the base of Mt. Washington, N. H., there are associated with the typical form the two varieties described below. There is also considerable variation in the venation. The two veins extending from the tip of the discal cell may be quite widely separated, close together, or fused and petiolate. A few specimens have an angle and stub-a vestige of a fourth vein arising from the discal cell. The latter variation is best shown 
in a series from Lake Nipigon, Ontario, collected by N. K. Bigelow.

Beris annulifera var. luteipes var. nov.

Beris morrisii of authors, not Dale.

Femora, tibiæ and posterior metatarsi entirely yellow, the front and middle metatarsi yellow except the tip, the remaining tarsal joints blackish.

Holotype and allotype Seattle, Wash. (O. B. Johnson); Denver, Col. (Oslar); Kearney, Ontario (M. C. Van Duzee); Lake Nipigon, Ontario, (Bigelow), collection of C. W. Johnson. Glen House, and Bretton Woods, N. H., St. Johnsbury, Vt. (Boston Soc. Nat. Hist.).

This form is more prevalent in the females than in the males.

Beris annulifera var. brunnipes var. nov.

All of the femora and tibiæ dark brown, the extreme tips of the femora and basal third of the tibiæ yellow, the tarsi entirely dark brownish black.

Holotype and allotype, Parroquet Island, Labrador, July 21, 1887, "Arethusa coll." (S. Henshaw). In the collection of the Boston Society of Natural History. Paratypes from the same locality in the Museum of Comparative Zoology. There are also specimens from Bretton Woods, N. H. in the Society's collection, and from the mountains east of Codroy, Newfoundland, July 19, (P. G. Bolster) in the author's collection. 

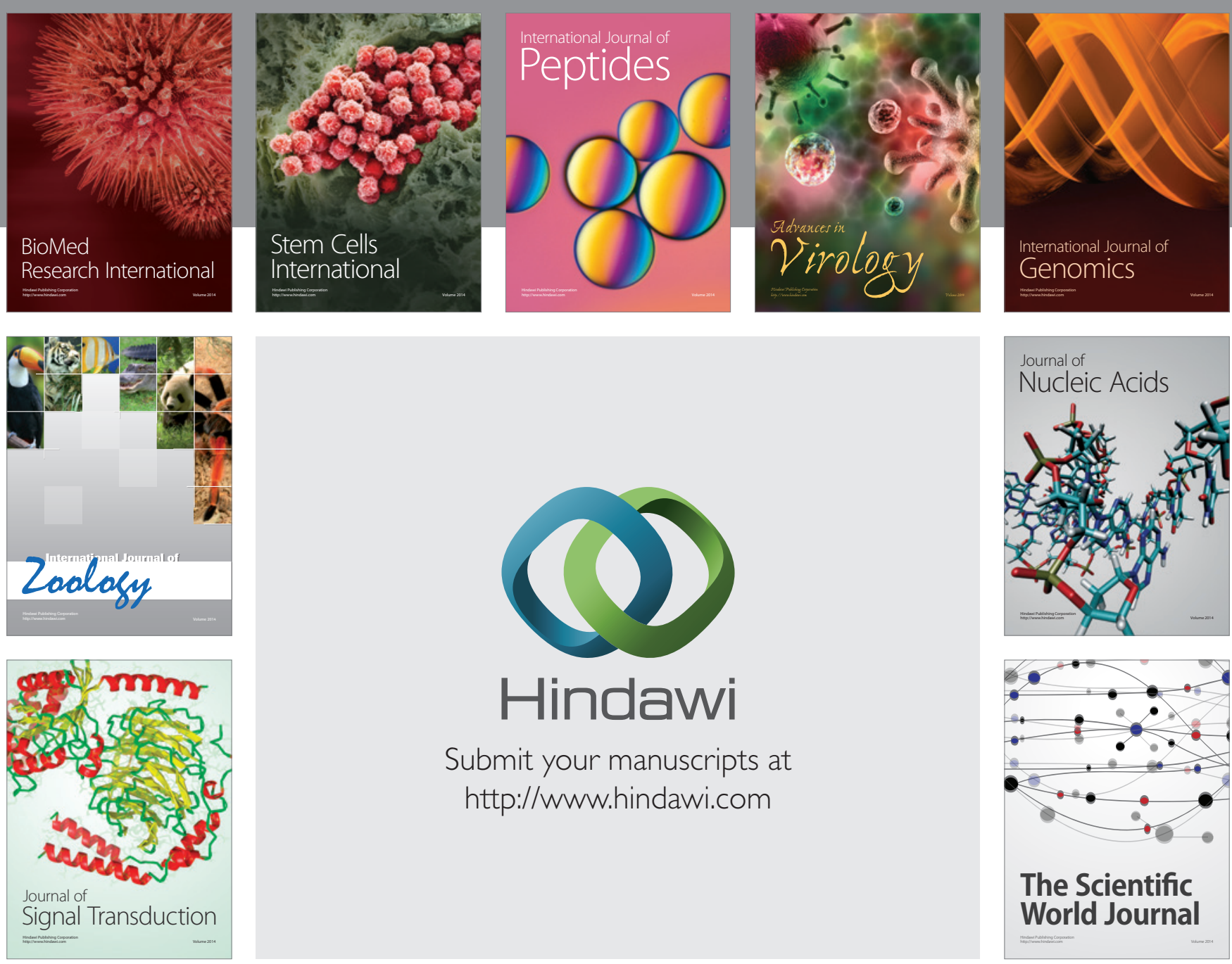

Submit your manuscripts at

http://www.hindawi.com
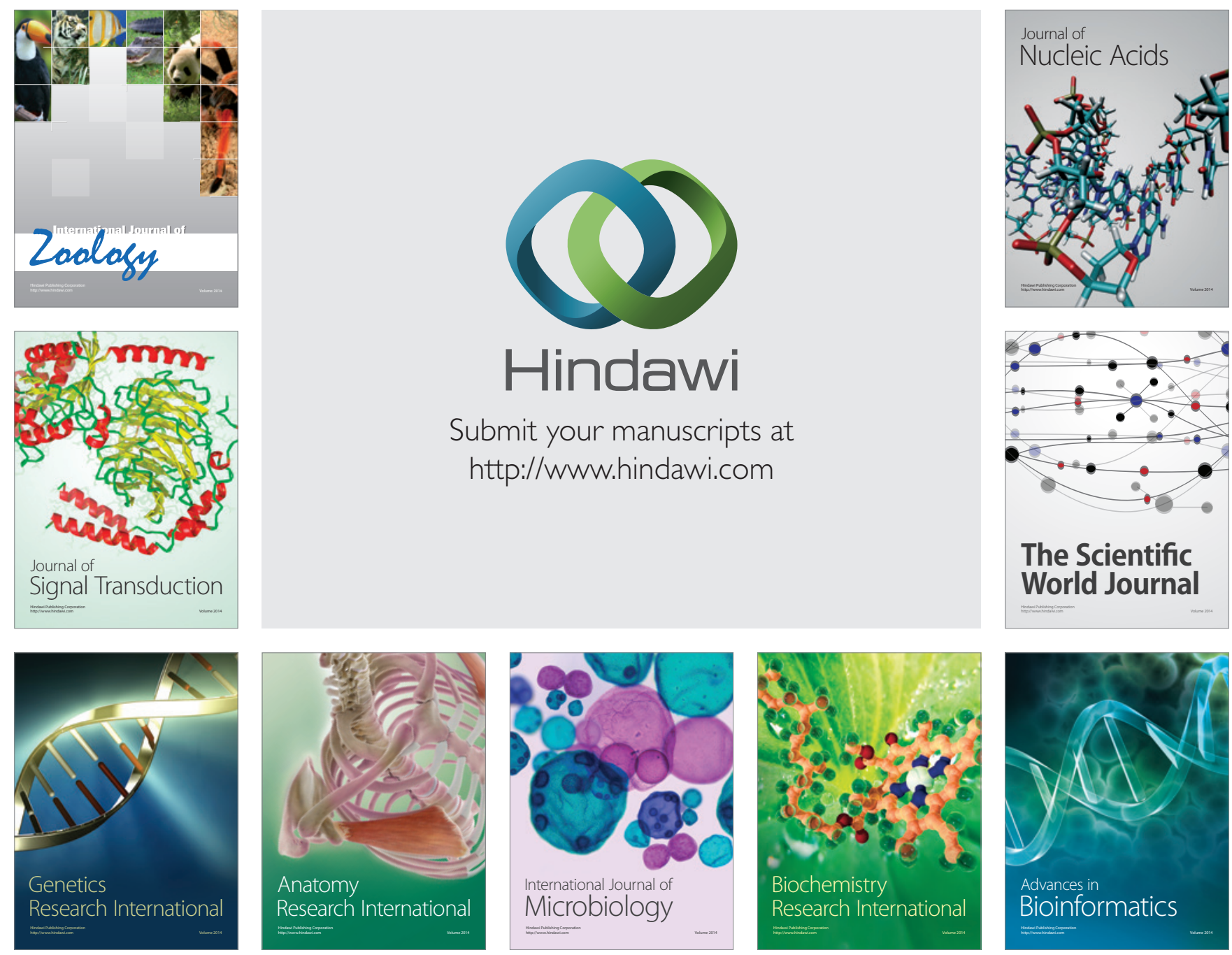

The Scientific World Journal
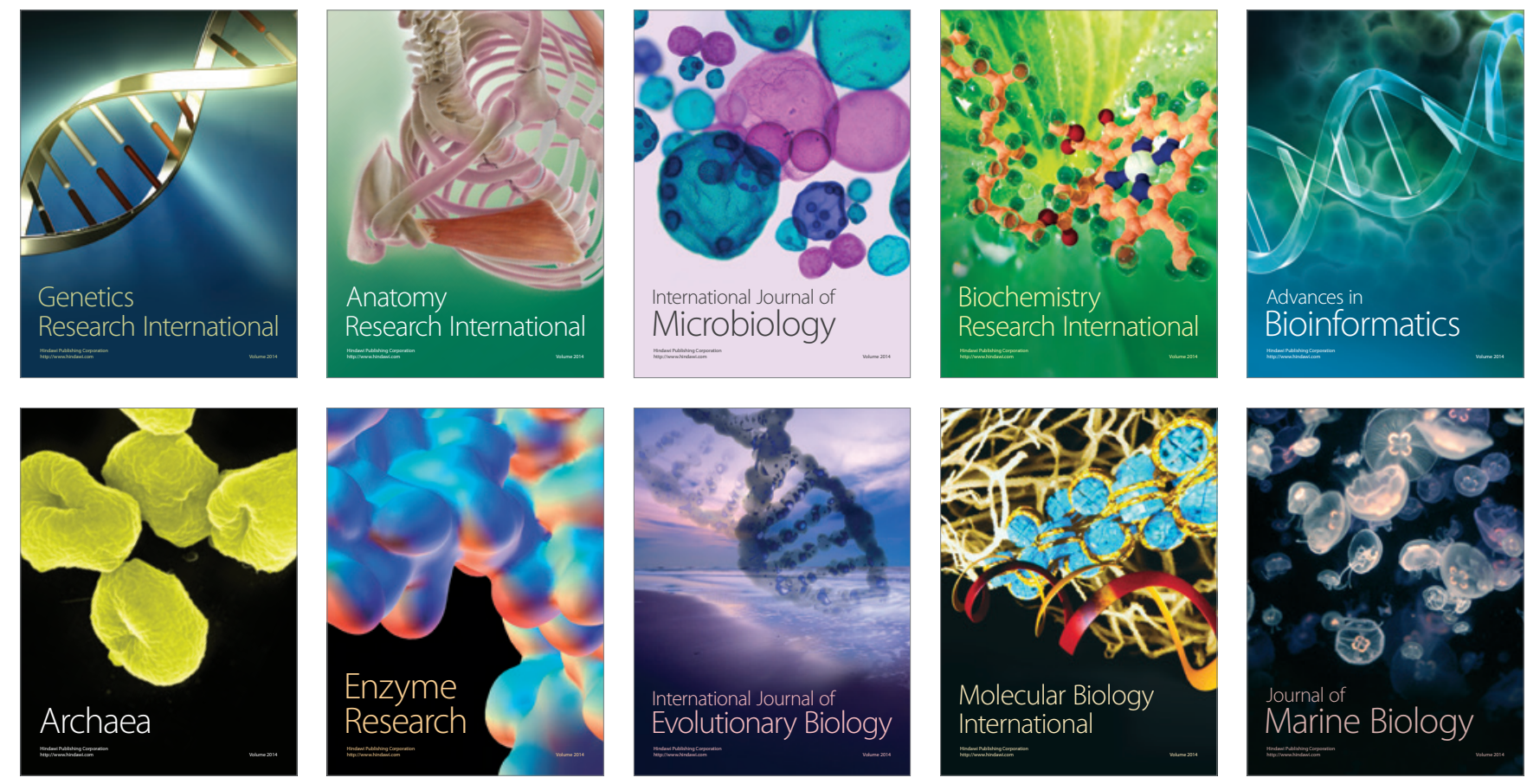